\title{
COMMENT
}

DOI: $10.1057 /$ s41599-018-0070-3

\section{Orientation towards otherness in the social and literary spaces of today's Europe}

Rosario Arias (i) ${ }^{1} \&$ Martyna Bryla ${ }^{1}$

\section{ABSTRACT}

This paper addresses current narratives on refugees and Muslim others within the social and literary spaces of today's Europe. Drawing on Sara Ahmed and others, it sets out to better comprehend what lies behind European fears of the other and, in doing so, raise questions about the ways of facing those who are desperately knocking on Europe's door.

${ }^{1}$ Universidad de Málaga (Spain), Málaga, Spain. Correspondence and requests for materials should be addressed to R.A. (email: rarias@uma.es) 


\section{Introduction}

ecent terrorist attacks in Europe have reinforced and consolidated anti-refugee discourse. Fear of otherness has been assuming different shapes, ranging from official, institutionalized policies to individual positions on the thorny 'problem of refugees'. In this paper, we do not attempt to analyse the state of affairs from the point of view of sociology and politics. Rather, we wish to address current European narratives on refugees and Muslim others, drawing on Sara Ahmed's phenomenological philosophy, particularly her concept of orientation. In doing so, we hope to dig into European fears underlying the way we face the other to understand what they may tell us about ourselves and inquire whether the change of focus is possible. We will look at the discursive dimension of the anti-refugee narrative, but also approach the present absence of otherness in bodily terms. Since both of us study literature, we will at times turn to it to help us illustrate our point.

\section{Orientation towards otherness}

In his groundbreaking Orientalism, Edward Said famously revealed the Orient to be an assemblage of mental maps and socio-cultural attributes constructed, represented and consolidated through the discourse of orientalism, a large-scale enterprise which, ultimately, served to define and consolidate Western identity, since 'European culture gained in strength and identity by setting itself off against the Orient as a sort of surrogate and even underground self (Said, 2003, p 3). In Queer Phenomenology (2006), Sara Ahmed reaches for Said's orientalism to theorize the phenomenology of race. Ahmed's guiding concept is that of orientation and she points out the linguistic resemblance between the two words: Orient, she argues, already 'refers us not just to space or to directionality, but also takes us in a specific direction' (Ahmed, 2006, p 112). Thus, the Orient, and hence also orientalism, encompasses the idea of being orientated towards a specific location. Importantly, in Ahmed's phenomenological philosophy, being orientated towards is an intentional form of facing something that is other than me-yet the quality of 'not being me' reasserts my own location as it 'always reflects back or shows where one is located' (Ahmed, 2006, p 115).

Ahmed introduces a distinction between orientation towards and around to conceptualize the paradox of gazing at the other which is at once a form of consolidating the self. Thus, ' $[\mathrm{b}] \mathrm{y}$ being directed toward the orient, we are orientated "around" the Occident. Or, to be more precise, the Occident coheres at that which we are organized around through the very direction of our gaze toward the Orient' (Ahmed, 2006, p 116). Yet, where Said is interested in texts, Ahmed pays attention to bodies. In this sense, orientalism involves affinity of bodies that share the Orient as their common object of desire and in so doing cohere by facing the same direction. This idea of bodies cohering around the West by being orientated towards the Oriental other leads Ahmed to the analysis of spaces as racialized, or of race as being phenomenological. She draws on Maurice Merleau-Ponty's idea of habitual body, which does not interfere in, or to put it differently, which 'trails behind' in the performing of an action (Ahmed, 2006, p 130), to represent whiteness in terms of a bodily attribute, a given that remains in the background unless it is faced with blackness.

To better understand the mechanics of what Ahmed is talking about, let us turn for a moment to recent world literature. In Gary Shteyngart's Little Failure: A Memoir (2014), the protagonist, is a Soviet Jew who has never consciously thought of being white (his whiteness 'trailing behind' him as opposed to his Russianness) until he has been faced with blackness: 'We are refugees and even Jews, $[\ldots]$ but we are also something that we never really had the chance to appreciate back home. We are white' (109). Interestingly, his is not an encounter with embodied blackness but rather an orientation towards what dark skin stands for. In fact, '[o]ver in the leafier parts of Kew Gardens and Forest Hills [of New York], the tribal hatred of blacks and Hispanics stands out partly because there aren't really any blacks or Hispanics' (Shteyngart, 2014, p 109, our emphasis). The protagonist comes to appreciate his hitherto habitual whiteness because he realizes that it signifies not being black or dark-skinned, blackness being a designated ethnic repository of social fears and anxiety. This fear of the imagined other becomes embodied through the very threat it represents-the visceral dread of what could happen if one were to run into the ethnic other. This is fear in Brian Massumi's sense of the word: 'the anticipatory reality in the present of a threatening future. It is the felt reality of the non-existent, loomingly present as the affective fact of the matter' (Massumi, 2010, p 54). Therefore, although the fear of the other which Shteyngart is writing about in his memoir is felt in the present, it is in fact located in the future, operating as an open-ended threat, or an always valid possibility, whose affective force is so strong that it refuses to be rationalized.

A similar fear of otherness understood not as physical presence but as a what if scenario may be detected in the anti-refugee discourse of social and political spaces of present-day Europe. There, the place of blackness is taken by the quality of being a refugee. Much has been written about the nature of this fear from the sociological perspective, colonial links, or prejudice, while existing immigrant communities have been cited as reasons for the emergence and sustenance of the fear of 'what if they come'. What is most preoccupying is that this future threat that is felt in the present 'can have specificity and lead to decisive preemptive actions with a corresponding level of specificity without having "real substance" or objective "credibility". The preemptive actions taken in response to the threat are still logically and politically correct if they were commensurate with the urgency of the threat, if not with the urgency of the actual situation' (Massumi, 2010, p 59).

The fear of otherness, clad in a polished, seemingly rational language of far-right politicians, reverberates in social and domestic spaces of Europe, seeping into casual conversations, poisoning minds. Every time terrorism strikes, the fear grows in strength through association. Although there is little evidence "that Isis and other terror groups use refugee flows or that asylum seekers are prone to radicalisation" (Dearden, 2016), refugees are often identified with terrorists and thus as representing a direct threat to the apparent solidity of Europe. Let us take a closer look at this narrative. Within the anti-refugee discourse, the arrival of the other is heralded as the ultimate threat to the unified system of European values, customs, and hierarchies. Here, the question of national identity comes in. As the late sociologist Zygmunt Bauman observed in Identity: Conversations with Bernardo Vecchi (2004), identity's 'raison d'être was the drawing, tightening and policing of the boundary between "us" and "them"' (Bauman, 2004 , p 21). In other words, the idea of identity has been constructed on the opposition between 'belonging' and 'exclusion', as ' "[b]elonging" would have lost its lustre and seductive power together with its integrating/disciplining function had it not been consistently selective and constantly given flesh and reinvigorated by the threat and practice of exclusion' (Bauman, 2004, p 22).

The same rationale applies to the narrative in question. Refugees, with their distinct religious and social practices, are excluded from the realm of belonging that assumes shape through confrontation with those who do not fit in. Yet, while the idea of national identity of, say, Poland or Spain, may appear relatively easy to define (one could cite here a common language, traditions 
and cultural heritage) the question arises about the nature of European identity; this somewhat hazy concept which some of the modern-day tribunes like to appeal to in their anti-refugee speeches. What is, therefore, European identity? Or, to be more precise, what it means to be European for regular citizens of the 28 nations of the European Union? Our guess would be that for many of them Europeanness has a predominantly practical dimension, involving free movement of people and goods, the possibility of fuss-free international travel and the comfort of using the same currency. Curiously enough, the anti-refugee discourse maps European identity as much more solid a net; a close-knit tissue which the non-European others are bound to disrupt. Paradoxically, within the same discourse Europe may also be mapped as corrupt, insane and ready to 'commit suicide' by letting the other in (Sydow, 2016). These dramatically diverse mental mappings point to the extreme volatility and shapeshifting of the idea of European identity, which is conveniently exploited either as a metaphorical bulwark against the threat of otherness, or a dying animal desperately grasping for air.

It is the latter image that looms large over Michel Houellebecq's latest novel Submission (2015), which envisions the Islamization of France and the gradual transformation of Europe into a vast Muslim empire including such countries as Tunisia or Egypt. Although published in the atmosphere of scandal (the book came out on the day of the Charlie Hebdo attack) and Houellebecq's alleged islamophobia, the novel's focus is hardly anti-Islamic. Rather, it portrays France and Europe in ideological and spiritual decay, unable to preserve its integrity and rapidly submitting to those whose political vision seems more solid and far-reaching. Submission is thus a novel about the collapse of the political and intellectual elites of Europe that, like the narrator of the novel, a disillusioned middle-aged academic called Francoise, are subsisting on the remnants of their past prime, and whose decision to submit to the new political forces is dictated by a mixture of resignation, commodity, egotism and lewdness (as a fresh convert Francoise is promised a hefty position at the newly Islamized Sorbonne and a selection of young wives).

Asked about his attitude to Islam in the aftermath of the novel's publication, Houellebecq declared that islamophobia is more about fear than hatred and admitted that in Submission he has deliberately played on the European fear of Islam which, he argues, has become omnipresent by now (Chrisafis, 2015). Thus, even though the fear of Islam may not be the subject of the novel, it underlies the dystopian representation of Europe that Houellebecq constructs in Submission. It is the same fear that drives the anti-refugee discourse, and, as the Slovenian philosopher Slavoj Žižek points out, the question that we should be asking ourselves is not whether the fear is well-founded, but rather 'what does this obsession with the immigrant threat tell us about the weakness of Europe'? (Žižek, 2016). To return to Ahmed's terminology, Žižek's question concerns thus the correlation between the European orientation towards Muslim otherness and around Western selfhood, as the way we face it reflects back on us.

One possible answer is offered by Zygmunt Bauman who identifies the European fear of refugees with the fear of uncertainty and precariousness. Refugees, argued Bauman in a 2016 interview with $\mathrm{Al}$ Jazeera, are people who in a matter of days have lost everything that provided solidity to their existence ( $\mathrm{Al}$ Jazeera, 2016). Homeless, jobless and frequently suffering from the loss of their loved ones, those people have been excluded and displaced from the life as they know it by the merciless 'wind of history'. Their sudden vulnerability and precariousness reminds members of the precariat, the rapidly growing class of the disillusioned, of their own condition of uncertainty, brittleness and fragility in the world where political institutions are no guarantee against social and emotional precariousness. Since the precariat lives by liquid anxiety, a diffused fear of danger that may strike unannounced and at any time, the displaced become a further source of distress, because they operate as 'walking dystopias' or the 'harbingers of bad news' (IWM, 2015), not only embodying the precariat's fears but also convincing it that these are not unfounded.

This takes us back to Massumi's affective fact of the matter. In the context of the anti-refugee discourse, this curious turn of phrase may be applied to express the combination of the emotional impact of liquid fear, fuelled by irrational and contradictory mappings of European selfhood and Oriental otherness, with the alleged solidity of socio-political realities which are about to be radically transformed once the other has penetrated Europe. Interestingly, the narrative which blends the liquid and the solid, affects and facts seems to be most common in countries, where the number of Muslims amounts to a fraction of the population. There, 'the affective fact' of the other radically transforming the sociopolitical tissue of the country and disrupting its identity is construed by far-right politicians, like Jarosław Kaczyński in Poland or Viktor Orban in Hungary, whose speeches solidify liquid fears into stone-hard prejudice, effectively shaping foreign politics. If it is true that, as Bauman argues, the fear of the other reflects the self's inner insecurities, then it is necessary to dig into the latter to realize what national demons drive the anti-refugee discourse and how they are being exploited by nationalistic voices to manipulate the public opinion. Most importantly, however, it is necessary to separate the paranoiac affective fact of the matter, which conflates refugees with terrorists-to-be, from real terrorism, as 'the task is to talk openly about all the unpleasant issues without a compromise with racism' (Žižek, 2016).

If until now we have used the term precariat to refer to the state of insecurity, fragility, and fear, in Bauman's sense of the word, it is time we expanded it to account for the bodily dimension of vulnerability as a common denominator in human relations. By doing so, we will be able to address alterity and the fear it provokes in terms of processes of turning towards the other that take place not only in the realm of discourse and imagined communities, as it happens for instance in the countries of East-Central Europe, but also in social spaces which bodies occupy and where they interact together. In her discussion of the ethics of (unchosen) cohabitation, following Hannah Arendt, Judith Butler points to precarity, the root word for precariat, which she sees in terms of a relationship between vulnerability and a politics of the body, since 'precarity is indissociable from that dimension of politics that addresses the organization and protection of bodily needs. Precarity exposes our sociality, the fragile and necessary dimensions of our interdependency' (Butler, 2012, p 148). Butler perceives precarity as central to the concept of cohabitation in which bodily beings depend upon one another as much as they depend on social and political institutions (Arias, 2018). Ahmed's notion of orientation evidently shares Butler's preoccupation with bodily proximity and interdependence. In her discussion of the racialization of social spaces, the scholar posits that '[s]paces acquire the "skin" of the bodies that inhabit them' (Ahmed, 2006, p 132). Skin refers here to the normative whiteness of bodies that through likeness and proximity, through the process of being orientated around whiteness, 'make spaces white'. This whiteness is invisible to those that inhabit it and, as mentioned earlier in this paper, it will remain so unless contrasted with their opposite. In the case of the Muslim other, it is not so much the skin colour as clothing and facial features that make him or her 'feel exposed, visible, and different when they take up this space' (Ahmed, 2006, $\mathrm{p}$ 133). If this unsolicited visibility remains moderate in the times of peace, it increases dramatically, whenever terrorism strikes.

Last summer a woman was fined by a group of police officers in Nice, France for wearing a pair of leggings, a tunic and a 
headscarf on a public beach. It is noteworthy that the event, or a burkini scandal, as tabloid press would likely call it, took place in the aftermath of the Bastille Day terrorist attack in which the driver of a cargo truck deliberately drove into crowds of people. In the wake of the tragedy, several French towns introduced a ban on burkini, Nice being one of them. The aforementioned event had been poignantly captured in a photograph which made headlines around the world. It shows the woman being approached by four police officers. Calm and unsuspecting, she is resting on the beach dressed in a black-and-blue ensemble amidst a number of swimwear-clad men and women. At first sight, she seems to be the only fully-dressed person on this beach, but a closer look reveals a fully-clad teenage boy sitting to her right. He too is clearly wearing an outfit that might be considered inappropriate for the beach, yet his clothes, a black t-shirt and a white cap seem to be 'Western' enough not to raise any suspicion or interfere with 'good morals and secularism', which were cited as the rationale behind the burkini ban (Quinn, 2016). There is another photograph in which the woman, police officers towering over her, is shown removing her blue tunic to reveal a black vest underneath. It is hard not to feel a sense of unease at the violent clash between the tranquil seaside and the imposing police officers suddenly plunged into the holiday landscape. One almost senses the humiliation and discomfort of the woman who was reported to have said that she 'had no intention of swimming', and who was forced to remove her tunic to make herself more 'secular-looking'.

As the above vignette shows, the problematic, non-Western clothes provide a pretext for sanctioning a certain kind of orientation towards the Muslim other, or what Ahmed would term 'the institutionalization of certain "likeness"' (Ahmed, 2006, $\mathrm{p}$ 133). The Muslim woman is excluded from the realm of belonging because outwardly she disrupts the customary likeness of the Western beach, where a bikini and swim trunks are the markers of unity and sameness. By commanding her to remove a piece of clothing, the police officers force her to fit in the space of the beach which, although usually associated with freedom and the possibility of 'letting go', becomes institutionalized to reflect the common orientation towards the non-Western other, which at the same time reflects the West's coherence around itself. Western bodies thus come together in a shared orientation which, however, renders the other precarious and vulnerable. The ethics of cohabitation, to use Butler's turn of phrase, become disrupted through the conflation of narratives: as the example of the teenage boy demonstrates, it is not so much the woman's clothing that arises suspicion, but rather the association between the clothing, which functions as the signifier for otherness, and the narrative of fear exacerbated by the recent terrorist attack. The result is an orientation that sanctions exclusion.

As the above examples of discursive and bodily orientations demonstrate, fear is at the heart of the way we face the other within the society and regulate their presence (or absence) among us. As we turn towards the other, we also orientate or cohere around the self, the fear seeping into the spaces we live in and forming a sticky interface between us. Sometimes it will spill in a xenophobic outburst, but most of the time it will solidify into indifference and the conviction that it is better to stay away and mind one's own business, which in turn breeds ignorance. Let us once again reach to recent literature to illustrate this point. Unlike Houellebecq, who taps into European fear of Muslim otherness to create a dystopia, Just Another Jihadi Jane (2016) by Tabish Khair, an Indian-born author and academic based in Denmark, explores a real-life scenario in which a London-based Muslim girl, Jamilla, flees the country to fight along the ISIS. Jamilla does not suffer from an overt discrimination or race-based hatred. However, stuck between an orthodox, self-contained family and a disinterested surrounding, she feels misunderstood and displaced, which eventually leads her to pursue a sense of belonging in the black-and-white realm of religious and political fundamentalism. Although Khair's book does not attempt to psychologise Jamilla's radicalization, as it focuses instead on the process of falling into the trap of fanaticism, it does, albeit very subtly, point finger at the indifference and ignorance that surround her both in her Muslim household and in the community. At one point the girl, who dons traditional Muslim garb, is accosted by an elderly woman who berates her for 'letting down [her] sex and not fitting into the culture' (Khair, 2016, p III). The woman's rationale seems to be as extraneous as the explanation behind the burkini ban, for both involve an orientation that is decidedly one-sided: the understanding of the other's motives is precluded by an orientation around oneself and the preconceptions and assumptions it involves.

That said, Khair's book is not a didactic affair. It neither condemns the woman's simplistic critique of Jamilla, nor tries to blame the girl's transformation into a Jihadi Jane on Western lack of interest. Khair is a sharp observer though, whose 'gentle humour anticipates and outmanoeuvres the ready prejudices of his characters and readers, indulging and sparing neither' (Sinha, 2017). In doing so, it hints at the possibility of a different kind of orientation, which in the novel is embodied by a minor character, Jamilla's classmate: 'a large, amoebic red-faced James, always striving to see the other person's perspective' (Khair, 2016, p IX). This willingness to understand in spite of how hard it may sometimes be is what Bauman had been suggesting shortly before his death. He argued that the only way for the Europeans to appease fears and address the situation they are going through is through dialogue-an undeniably difficult and long-term one, but indispensable nonetheless (IWM, 2015). To engage in such a dialogue is to forgo a preconceived agenda woven out of stereotypes and preconceptions and assume the double role of a teacher and student that is ready to share his/her insights but is also open to learning new ones, and does not preclude the possibility of being proved wrong in the course of the exchange (IWM, 2015). Understood as such, 'dialogue is the proper response to the extent of diversification of humanity and the desirable mode of human interdependence and cohabitation' (Bauman and Raud, 2015, p 30, our emphasis). Necessarily, the shape which such dialogue will assume will depend on the existing orientations within the social spaces of Europe, some of which we have discussed earlier in this paper. Therefore, it will range from openly addressing and deconstructing discriminatory blanket narratives which equate refugees with terrorists, to questioning its opposite-what Zižek terms 'the tragic-comic spectacle of [Europe's] endless self-culpabilization', which he sees as utterly 'self-serving' and thus 'closed to a true encounter with the immigrant neighbour' (Žižek, 2016). Interestingly, before coming to the West people staying at refugee camps undergo orientation trainings that are meant to teach them how to find their way around in the new reality. Here orientation emerges as education, or education is an 'orientation device' (Ahmed, 2010, p 54) aimed at steering the newcomer in the right direction, i.e., such that will prove beneficial to them and to the society they are on the verge of entering. Engaging in a dialogue in Bauman's sense of the word thus implies mutual education which carries the potential for re-thinking and re-adjusting the ways we orientate towards others and around ourselve$\mathrm{s},{ }^{1}$ promising to 'elaborate the mutually beneficial modus vivendi with a difference' (Bauman and Raud, 2015, p 30).

Within the realm of mental maps, Polish psychologist Wojciech Eichelberger recommends starting with an imaginary dialogue with the Muslim other. He recommends forgoing political correctness and blurting out all the preconceptions, fears and prejudices that tend to be associated with the mental rubric of a Muslim person to an imagined stranger sitting in front of us. 
Then, he suggests taking up the other's place to inhabit his or her perspective, and responding to the diatribe with the same bluntness. The result, he says, may be surprising, for we may see that what we fear or despise so much in our representation of the other is in fact ours (Pawłowicz, 2017). Yet as Žižek unabashedly puts it, '[t]he point is $[\ldots]$ not to recognize ourselves in strangers, but to recognize a stranger in ourselves-therein resides the innermost dimension of European modernity. The recognition that we are all, each in our own way, weird lunatics, provides the only hope for a tolerable co-existence of different ways of life' (Žižek, 2016, our emphasis). What Žižek proposes here is to question Europe's orientation around itself, which sanctions everything that is familiar as correct and normative. It is in this change of focus that he perceives the hope for a tolerable co-existence, which is also the ultimate purpose of Bauman's idea of dialogue. Somewhat counterintuitively, difference (not just between Europeans and Muslim immigrants but also within both peoples respectively) emerges here not as an obstacle but rather as a common denominator-as Bauman argued, dialogue promises to elaborate an inclusive mode of living that operates thanks to difference rather than despite it (IWM, 2015). This will only be possible, however, if coexistence is understood from the perspective of Butler's ethics of cohabitation, according to which 'the life of the other, the life that is not our own, is also our life, since whatever sense 'our' life has is derived precisely from the sociality, this being already, and from the start, dependent on a world of others, constituted in and by a social world' (Butler, 2012, p 140-141).

Olga Tokarczuk, a renowned Polish novelist, seemed to have Butler's ethics of cohabitation in mind when she said that she wished to see a banner saying: 'You are all children or descendants of refugees' hanging from the City Hall of Wrocław, the city she lives in, which in the course of history pertained variously to Poland, Bohemia, Prussia, and Germany (Wodecka, 2015). Indeed, the realization that so many of us are, in some way or another, migrants is no platitude. Even less so is the awareness that 'unwilled proximity and unchosen cohabitation serve [...] as the basis for our obligation [...] to invest institutions with the demand to seek to make all lives liveable and equally so' (Butler, 2012, p 146). Here is a narrative that entails 'keep[ing] open the possibility of changing directions and of finding other paths' (Ahmed, 2006, p 178) in the way we think about and act towards those that come knocking on Europe's door. As an alternative to the dead-end discourse of fear, it points towards an inclusive European future that does justice to the EU's somewhat forgotten motto of united in diversity.

Received: 21 November 2017 Accepted: 23 January 2018

Published online: 20 February 2018

\section{Notes}

1 Fortunately, this is not a pipe dream, as such initiatives are already taking place and their importance cannot be emphasized enough. For instance, last year Polish branch of Amnesty International published a moving video in which Europeans and refugees sit opposite each other and look into each other's eyes. The experiment shows a gradual change in orientation towards the other as he or she ceases to be an anonymous being and turns into a flesh-and-blood person with their own narrative, their hopes and dreams (https://www.youtube.com/watch?v=f7XhrXUoD6U\&t=232s).

\section{References}

Ahmed S (2006) Queer phenomenology: orientations, objects, others. Duke University Press, London

Ahmed S (2010) The promise of happiness. Duke University Press, Durham and London

Al Jazeera English (2016) Zygmunt Bauman: behind the world's 'crisis of humanity'. https://www.youtube.com/watch?v=EG63MkQb1r4
Arias R (2018) Wounded characters and vulnerable lives and places in Ian McEwan's Saturday. In: Onega S and Ganteau JM (eds) The paradoxical quest of the wounded hero in contemporary literature. Routledge, London and New York

Bauman Z (2004) Identity: conversations with Benedetto Vecchi. Polity Press, Cambridge

Bauman Z, Raud R (2015) Practices of selfhood. Polity Press, Cambridge

Butler J (2012) Precarious life, vulnerability, and the ethics of cohabitation. J Specul Philos 26(2):134-151

Chrisafis A (2015) Michel Houellebecq: Am I islamophobic? Probably, yes. Interview with Michel Houellebecq. The Guardian. https://www.theguardian. com/books/2015/sep/06/michel-houellebecq-submission-am-i-islamophobicprobably-yes

Dearden L (2016) UN report finds no evidence migration causes terror attacks and warns anti-refugee laws could worsen risk. Independent. http://www. independent.co.uk/news/world/europe/refugee-crisis-terrorism-linkmigration-un-expert-report-no-evidence-isis-uses-route-human-rightsa7377961.html

Houellebecq M (2015) Submission. English edition: Houellebecq M (2015) Submission: a novel (trans: Stein L). Vintage, London, Kindle file

IWM Vienna (2015) Diasporic terrorism. Patočka Memorial Lecture by Zygmunt Bauman. https://www.youtube.com/watch?v=SOT7ZbRCJWs

Khair T (2016) Just another Jihadi Jane. Periscope, Reading, Kindle file

Massumi B (2010) The future birth of the affective fact: the political ontology of threat. In: Gregg M, Seigworth GJ (eds) The affect theory reader. Duke University Press, London, p 52-70

Pawłowicz B (2017) Osiołek mojego partnera. Wywiad z Wojciechem Eichelbergerem. Zwierciadło 9(2051):108-111

Quinn B (2016) French police make woman remove clothing on Nice beach following burkini ban. The Guardian. https://www.theguardian.com/world/ 2016/aug/24/french-police-make-woman-remove-burkini-on-nice-beach

Said E (2003) Orientalism. Vintage Book, New York, 25th Anniversary Edition

Shteyngart G (2014) Little failure: a memoir. Penguin Books, London

Sinha I (2017) Just another Jihadi Jane by Tabish Khair: Review. Eye-opening story of Isis recruitment. The Guardian. https://www.theguardian.com/books/ 2017/apr/14/just-another-jihadi-jane-tabish-kair-review-isis

Sydow K (2016) Troska, strach, wrogość. Dyskurs o uchodźcach i migrantach w Polsce i Niemczech. The Heinrich Böll Foundation Website. https://pl.boell. org/pl/2016/07/25/troska-strach-wrogosc-dyskurs-o-uchodzcach-imigrantach-w-polsce-i-niemczech

Wodecka D (2015) Wywiad z Olga Tokarczuk. Wyborcza.pl. http://wyborcza.pl/ 1,75410,18999849,olga-tokarczuk-laureatka-nike-2015-ludzie-nie-bojcie-sie.html

Žižek S (2016) What our fear of refugees says about Europe. New Statesman https://www.newstatesman.com/politics/uk/2016/02/slavoj-zizek-what-ourfear-refugees-says-about-europe

\section{Acknowledgements}

The research carried out for the writing of this essay has been financed by a research project awarded by the Spanish Ministry of Science and Innovation (ref number: FFI2017-86417-P), and Martyna Bryla's post-doctoral research grant from Universidad de Málaga, Spain.

\section{Additional information}

Competing interests: The authors declare no competing financial interests.

Reprints and permission information is available online at http://www.nature.com/ reprints

Publisher's note: Springer Nature remains neutral with regard to jurisdictional claims in published maps and institutional affiliations.

\footnotetext{
Open Access This article is licensed under a Creative Commons AY
adtribution 4.0 International License, which permits use, sharing, appropriate credit to the original author(s) and the source, provide a link to the Creative Commons license, and indicate if changes were made. The images or other third party material in this article are included in the article's Creative Commons license, unless indicated otherwise in a credit line to the material. If material is not included in the article's Creative Commons license and your intended use is not permitted by statutory regulation or exceeds the permitted use, you will need to obtain permission directly from the copyright holder. To view a copy of this license, visit http://creativecommons.org/ licenses/by/4.0/.
}

(C) The Author(s) 2018 